\title{
DESIGN INFORMATION SYSTEM OF EMPLOYEES TARGET WITH NEURAL NETWORK BACKPROPAGATION
}

\author{
Agus Sifaunajah \\ Faculty of Information Technology KH.A. Wahab Chasbullah University Jombang \\ Email : agus.syifa85@gmail.com
}

Kusworo Adi

Faculty of Saints and Mathematics Diponegoro University

Email : kusworoadi@gmail.com

Farikhin

Department of Mathematics Diponegoro University

Email : farikhin@undip.ac.id

\begin{abstract}
Assessment of the performance of civil servants (PNS) is still considered less objective and subjective tended to by some, so we need a solution to improve the objectivity of assessment. The target of employee work (SKP) is one solution to improve objectivity in the assessment of civil servants. Backpropagation is one of the methods in neural networks which is implemented in the information systems of SKP for used classification of data performance. Observation and literature became the method of data collection in this study. Web-based information systems of skp are facilitated for employees in the preparation of assessments. Backpropagation can be implemented to perform data classification of performance.
\end{abstract}

\section{Keyword: Neural network; Backpropagation, Classification, SKP}

Received: 2 February, 2017; Accepter: 15 March, 2017

\section{INTRODUCTION}

Some algorithms can be used for classification (Daniele et al, 2011), such as artificial neural networks (Hyunsoo et al, 2013) and C4.5 algorithms (Kemal and Salih, 2009), where one method with another has its own characteristics. Artificial neural networks (ANN) have been used over the past several decades in a wide range of applications (Saad and Wunsch, 2007). It is often useful to construct symbolic representations of basic rules or functions that are computed with the network. When decision support applications, such as in clustering or clustering issues, it is often desirable to understand how ANN determines its decision. Such an understanding is often desirable in areas such as data mining and systems engineering.

Backpropagation is one of the learning algorithms in artificial neural networks. The learning process in backpropagation is done by adjusting each artificial neural network weight with reverse direction based on error value in the learning process. Backpropagation works in iterative by using a set of data samples (data training), comparing the predicted values of the 
network with each sample of data. In each process, the relational weights on the network are modified to minimize the Mean Squared Error (MSE) value between the predicted value on the network and the real value (Kusrini and Taufiq, 2009).

One of the essential components in the education system in college is the lecturer. The role, duties, and responsibilities of lecturers are very important in realizing the goals of national education. Law Number 14 the Year 2005 regarding Teachers and Lecturers and Government Regulation of the Republic of Indonesia Number 37 the Year 2009 explains that lecturers are professional educators and scientists with the main task of transforming, developing and disseminating science, technology, and art through education, research, and community service. This study aims to implement artificial neural network back propagation in building a classification information system employee job target.

\section{THEORETICAL FRAMEWORK}

\subsection{Artificial Neural Networks}

algorithm learning based neural network is one form of a new approach in classification techniques. This method utilizes the previous knowledge that is mathematically calculated by other algorithms, such as PCA, Lars, C.45 and SVM (Hyunsoo et al, 2013).

Backpropagation is one of the supervised learning algorithms in artificial neural networks and is commonly used by perceptrons with multiple layers. This propagation algorithm has been widely applied. This algorithm uses an error value in the output to convert synaptic weight values to all existing neurons (Kusumadewi, 2003). In general, the model of back propagation algorithm is as follows:

$$
\begin{aligned}
& \mathrm{Z}_{\mathrm{j}}=\mathrm{F}\left(\mathrm{v}_{0 \mathrm{j}}+\sum_{\mathrm{i}=1}^{\mathrm{n}} \quad \mathrm{x}_{\mathrm{i}} \mathrm{v}_{\mathrm{ij}}\right. \\
& \mathrm{Y}_{\mathrm{k}}=\mathrm{F}\left(\mathrm{w}_{0 \mathrm{k}}+\sum_{\mathrm{i}=1}^{\mathrm{p}} \quad \mathrm{z}_{\mathrm{j}} \mathrm{w}_{\mathrm{jk}}\right.
\end{aligned}
$$

The $Z_{j}$ value is an activation function performed on the $x_{i}$ input signal sent to the hidden layer. While the value of $Y_{k}$ to the sum of input signals that have the weight $Z_{j}$ sent to the output layer (Puspitaningrum, 2006).

In general, the back propagation architecture consists of 3 parts covering the input section, hidden layer, and output. Each unit in the input layer is connected to each unit in the hidden layer, so each hidden layer is connected to each unit in the output layer, as shown in Figure 1:

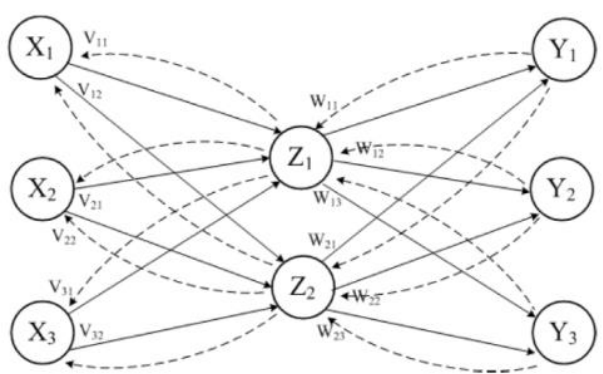

Figure 1. Backpropagation Network Architecture

The workings of backpropagation networks can be described as follows: the first time, the network is initialized by using weights set with random-patterned numbers. Then, the data that is functioned as a sample training (sample training) is entered into the network. Examples 
of training consist of input vector pairs and target output vectors. The output of the network is an actual output vector. Then, the actual output vector of the network is compared to the target output vector to find out whether the network output matches the expectation that is equal to the target output.

Errors or errors arising from the difference between the actual output and the target output are then calculated and used to make improvements to the relevant weights by reprocessing the error. Any weight changes that occur are expected to reduce the amount of error.

The epoch or cycle in each training pattern performed on all sets continues to run until the performance on the network reaches the desired level or until the stop condition is met. After the training process, then the application algorithm can be applied (Puspitaningrum, 2006).

\subsection{Rules of Assessment of Employee Work Objectives}

Regulation of the Head of State Employment Agency (BKN) No 1 of 2013 then provides provisions on the implementation of Government Regulation No. 46 the Year 2011. In preparing the SKP, a civil servant should note that the SKP field must be clear, measurable, relevant, achievable and targeted.

The elements in the preparation of the SKP are as follows:

1. Activity tasks

In the composition of the SKP that involves the activities of the job title should refer to the determination of performance or RKT. In carrying out the duties of office positions in principle the work is divided from the highest level of office to the lowest position in the hierarchy.

2. Credit Score

The unit of value of each item of activity and or the accumulation of the value of the items of activity to be achieved by a functional official in the framework of the career development concerned shall be determined by the number of credits to be achieved. Therefore, certain functional officials must set credit target targets to be achieved within 1 (one) year.

3. Target

In setting achievement targets on SKP include the following aspects:
a. Quantity (quantity target)
b. Quality (quality target)
c. Time (target time)
d. Cost (cost target)

The SKP assessment procedure is as follows:

a. The value of SKP achievement is expressed by numbers and information as follows:

Table. 1 Value of Achievement SKP

\begin{tabular}{|c|l|l|}
\hline No & \multicolumn{1}{|c|}{ Number } & Information \\
\hline 01 & $91-$ up & Verry good \\
\hline 02 & $76-90$ & Good \\
\hline 03 & $61-75$ & Enough \\
\hline 04 & $50-$ Down & Bad \\
\hline
\end{tabular}


b. Assessment of the SKP for each task task implementation is measured by 4 aspects, namely: quantity aspect, quality, time, and cost as follows:

i. Quantity aspect: the calculation uses the formula:

$$
\frac{\text { Output Realization }(O R)}{\text { Output Target }(O T)} \times 100
$$

ii. Quality aspect: calculation using the formula:

$$
\frac{\text { Quality Realization }(Q R)}{\text { Quality Target }(Q T)} \times 100
$$

To assess whether the output is qualified or not by using the following guidelines:

Table 2. Quality Guidelines

\begin{tabular}{|l|l|}
\hline $\begin{array}{c}\text { Value } \\
\text { Criteria }\end{array}$ & \multicolumn{1}{c|}{ Information } \\
\hline $91-100$ & $\begin{array}{l}\text { The work is perfect, no mistakes, no revisions, and } \\
\text { services above the specified standards etc. }\end{array}$ \\
\hline $76-90$ & $\begin{array}{l}\text { The work has 1 or 2 small mistakes, no major errors, } \\
\text { revisions, and services according to predetermined } \\
\text { standards etc. }\end{array}$ \\
\hline $61-75$ & $\begin{array}{l}\text { The work has 3 or 4 small errors, and no major errors, } \\
\text { revisions, and services meet the specified standards }\end{array}$ \\
\hline $51-60$ & $\begin{array}{l}\text { The work has 5 small errors and there are major } \\
\text { errors, revisions, and services not enough to meet the } \\
\text { specified standards etc. }\end{array}$ \\
\hline $50-$ down & $\begin{array}{l}\text { The work has more than 5 small mistakes and there } \\
\text { are big mistakes, unsatisfactory, revisions, under- } \\
\text { standard service etc. }\end{array}$ \\
\hline
\end{tabular}

iii. Aspects of Time

1. If the activity is not done then the realization of time 0 (zero), the formula used is:

$$
\frac{1,76 \times \text { Target Time }(\mathrm{TT})-\text { Realization Time }(\mathrm{RT})}{\text { Target Time }(\mathrm{TT})} \times 0 \times 100
$$

2. If the time aspect of the efficiency level $\leq 24 \%$ given the value of good up to very good, used the following formula:

3.

$$
\frac{1,76 \times \text { Target Time }(\mathrm{TT})-\text { Realisation Time }(\mathrm{RT})}{\text { Target Time }(\mathrm{TT})} \times 100
$$


4. If the time aspect of the efficiency level> $24 \%$ given the value of enough to bad, used the following formula:

$$
76-\left\{\left(\frac{1,76 \times \text { Target Time }(\mathrm{TT})-\text { Realisation Time }(\mathrm{RT})}{\text { Target Time (TT) }} \times 100\right)-100\right\}
$$

5. To calculate the percentage of time efficiency level of the time target, the following formula is used:

$$
100 \%-\left(\frac{\text { Realisation Time }(R T)}{\text { Target Time }(T T)} \times 100\right)
$$

iv. Cost Aspects

1. If the activity is not done then the realization of the cost of 0 (zero), used the formula as follows:

$$
\frac{1,76 \times \text { Target Cost }(T C)-\text { Realisation } \operatorname{Cost}(R C)}{\text { Target } \operatorname{Cost}(T C)} \times 0 \times 100
$$

2. If the efficiency level $\leq 24 \%$ (good value-very good), used the formula as follows:

$$
\frac{1,76 \times \text { Target Cost }(T C)-\text { Realisation Cost }(R C)}{\text { Target Cost }(T C)} \times 100
$$

3. If the efficiency level $>24 \%$, given the value of up to bad enough, using the formula as follows:

$$
76-\left\{\left(\frac{1,76 \times \text { Target } \operatorname{Cost}(T C)-\text { Realisation } \operatorname{Cost}(R C)}{\text { Target } \operatorname{Cost}(T C)} \times 100\right)-100\right\}
$$

4. To calculate the percentage of cost efficiency level of the target cost used the formula:

\section{Classification}

$$
100-\left(\frac{\text { Realisation } \operatorname{Cost}(R B)}{\text { Target } \operatorname{Cost}(T B)} \times 100\right)
$$

The classification technique is a systematic approach to construct a classification model of an input data set. Classification is the learning process of a target function $f$ which maps each set of attributes $x$ to one of the previously defined $y$ labels.

Classification techniques are suitable for predicting or describing datasets with binary or nominal types but less effective when used for ordinal data types. There are two types of classification models (Hermawati, 2013), namely:

- Descriptive modeling, which is a classification model that can serve as an explanation for distinguishing objects in different classes. 
- Predictive modeling, which is a classification model that can be used to predict unknown record class labels.

Systems that perform a classification are always expected to classify all data sets correctly. However, it can not be denied that the performance of a system cannot be $100 \%$ correct so that a classification system should also be measured its performance. One of the classification performance measurement model can be done by using confusion matrix (Prasetyo, 2012).

\section{METHODOLOGY}

Methods of data collection in this study are as follows:

a. Observation

Is a method of data collection by doing a direct observation of the object under study that includes the system and the files that will be processed into data.

b. Literature review

Is a method of collecting data by collecting data from various sources that support research either from books, scientific journals, proceeding papers and other articles that support research. The results of literature studies in the form of current theories and developments on classification systems and other supporting theories.

The object of this research is the employee target information system at Universitas KH.A. Wahab Chasbullah Jombang.

Procedure of the research to be conducted as presented in the following chart:

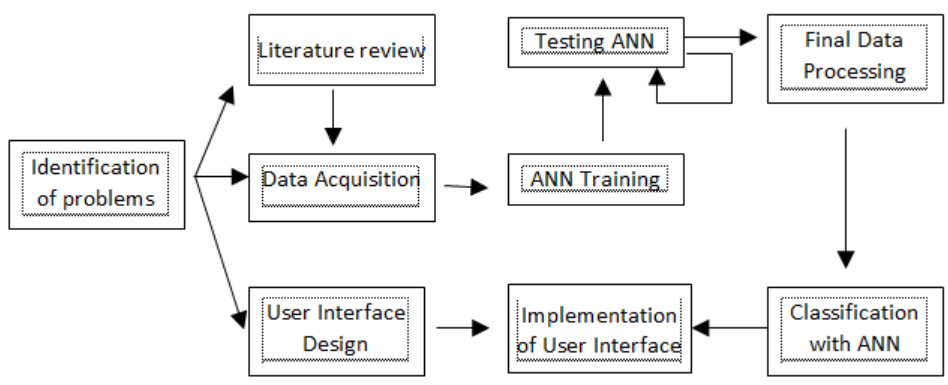

Figure 2. Research Procedure 
The system framework of this research is as follows :

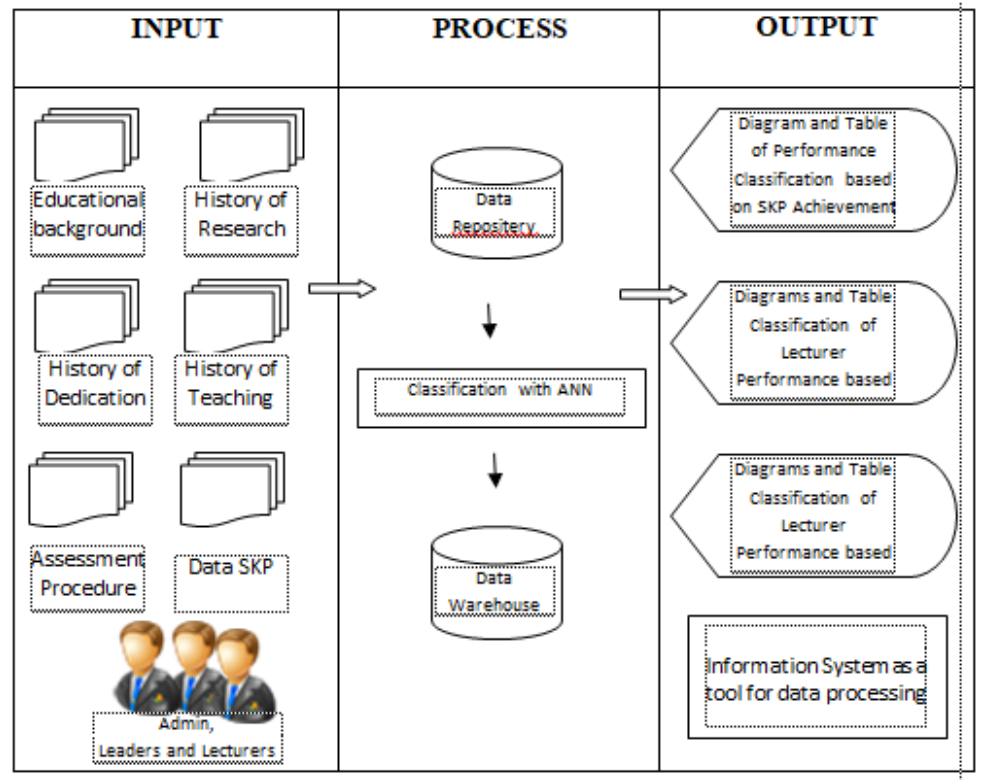

Representation of all the facts from "real world" into the application system to be built can be done by using entity relationship diagram. Entity Relationship Diagram (Diagram E-R) is a diagram consisting of a set of components and a set of relations that each represent the whole fact of the "real world".

The following is a form of E-R diagram of the SKP information system

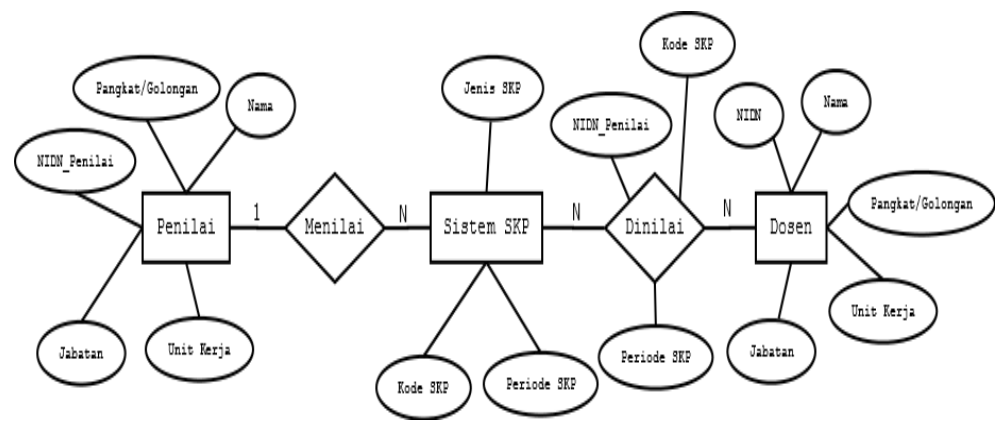

Figure 4. E-R Diagram of SKP Information

\section{RESULTS AND DISCUSSION}

Research Results

The result of research has been done by applying propagation neural network algorithm (JST BP) to perform lecturer classification process based on employee job target according to PP No.46 of 2011 showing graph and table of lecturer SKP achievement, lecturer academic position and aspect of lecturer SKP .

Applications used to display the results of the classification process consists of the frontend system and back-end system. The contents of the front end system are login, graph and lecturer data tables and classification results. The back end system contains master data input, 
skp data input, SKP parameter settings, processing results and SKP data reports that can only be accessed by the admin, lecturers, and leaders. With this application, the leader can more easily map the competence of human resources owned so that the improvement of competence can be a more appropriate target.

\section{System Implementation}

The following is the result of the implementation of artificial neural network back propagation in an employee target information system.

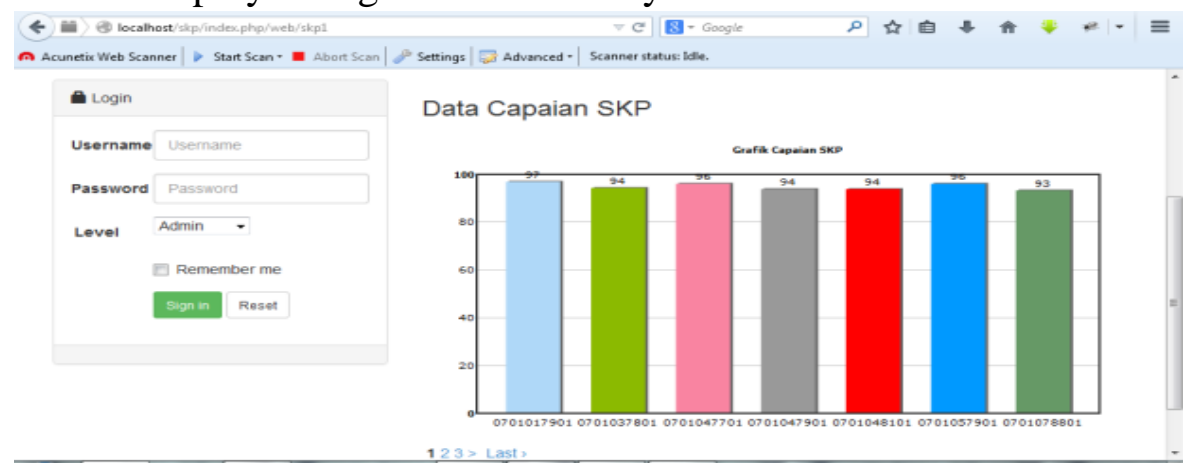

Figure 5. Graph of Data Achievement

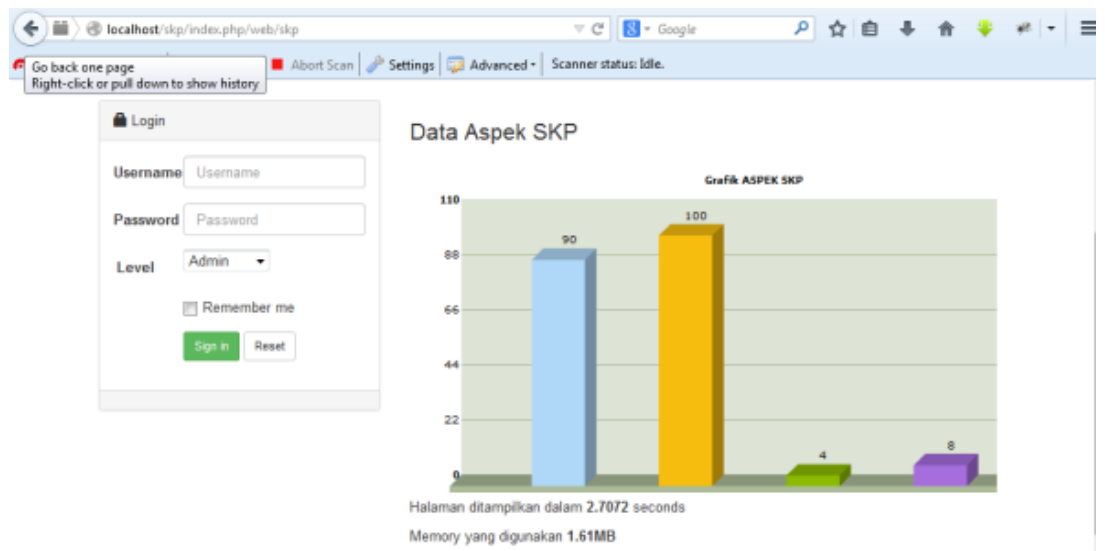

Figure 6. Graph of SKP Data Aspect

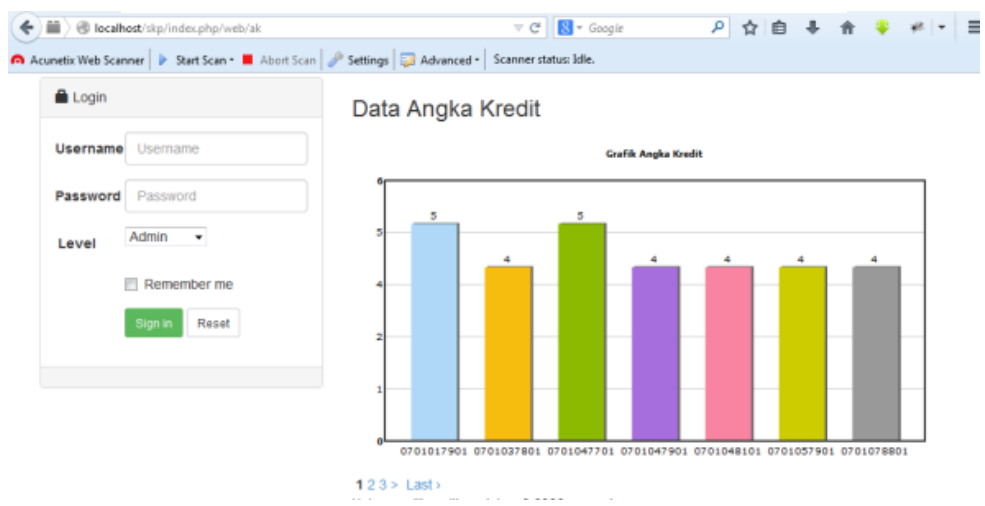

Figure 7. Graph of Credit Rate Data 


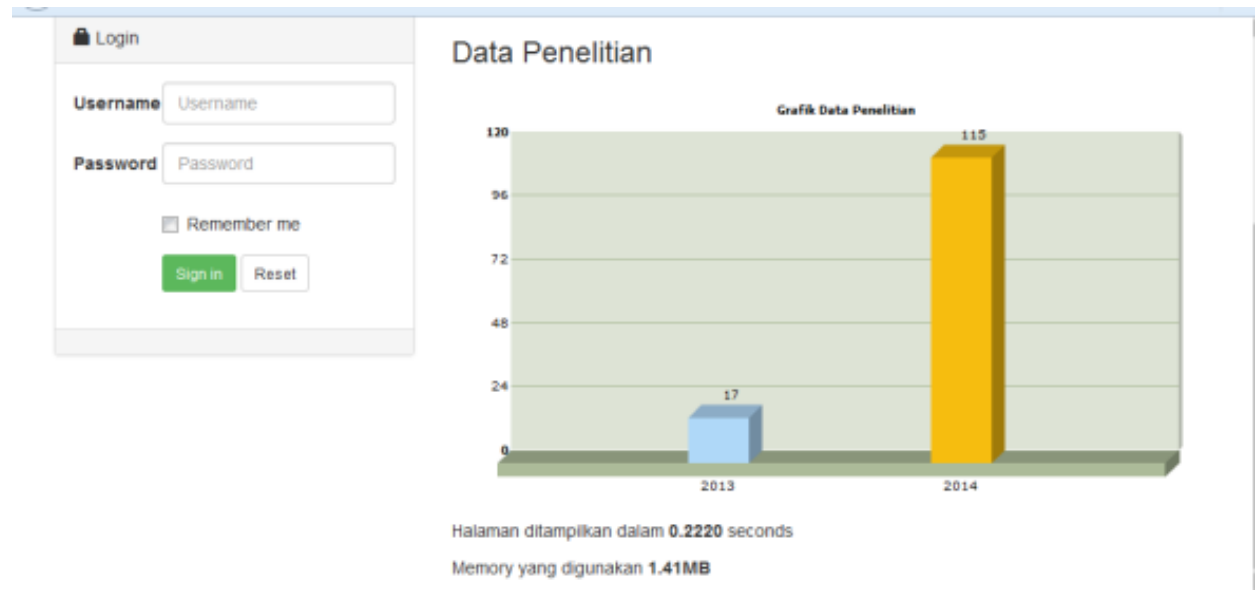

Figure 8. Graph of Research Data

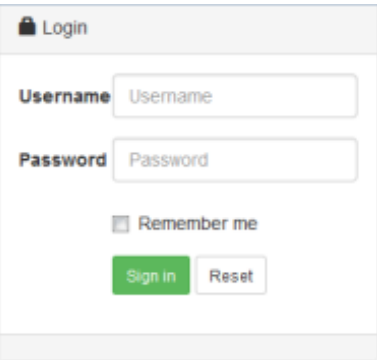

\section{Data Pendidikan}

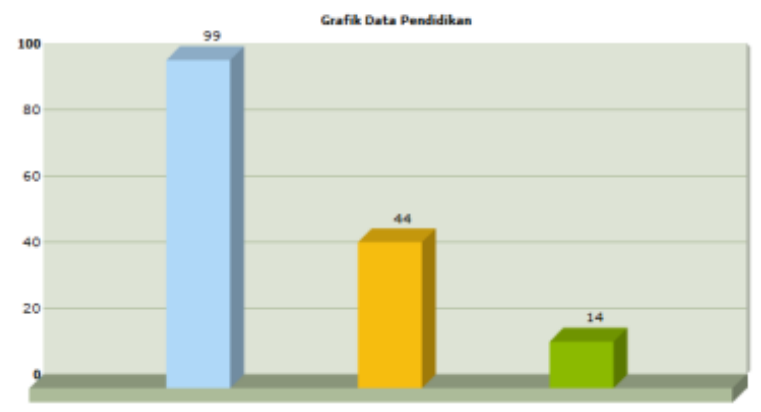

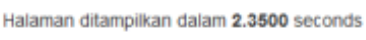

Memory yang digunakan $1.41 \mathrm{MB}$

Figure 9. Education Data Chart

\section{Implementation testing of Artificial Neural Networks Back Propagation}

Application of ANN BP in this system is used to perform data classification. In artificial neural networks, there is no set rule that can define the best network architecture. To find out the best network architecture, can be known by doing some testing until found the architecture with optimal results.

In this test, the best architecture is obtained by using 3 hidden layers. By adding the value of bias 1, determined the value of epoch 100 as well as using the value of learning rate 0.80 , using 20 data as the material of manual calculation using Ms. aid Excel. Obtained data as figure 10 below: 


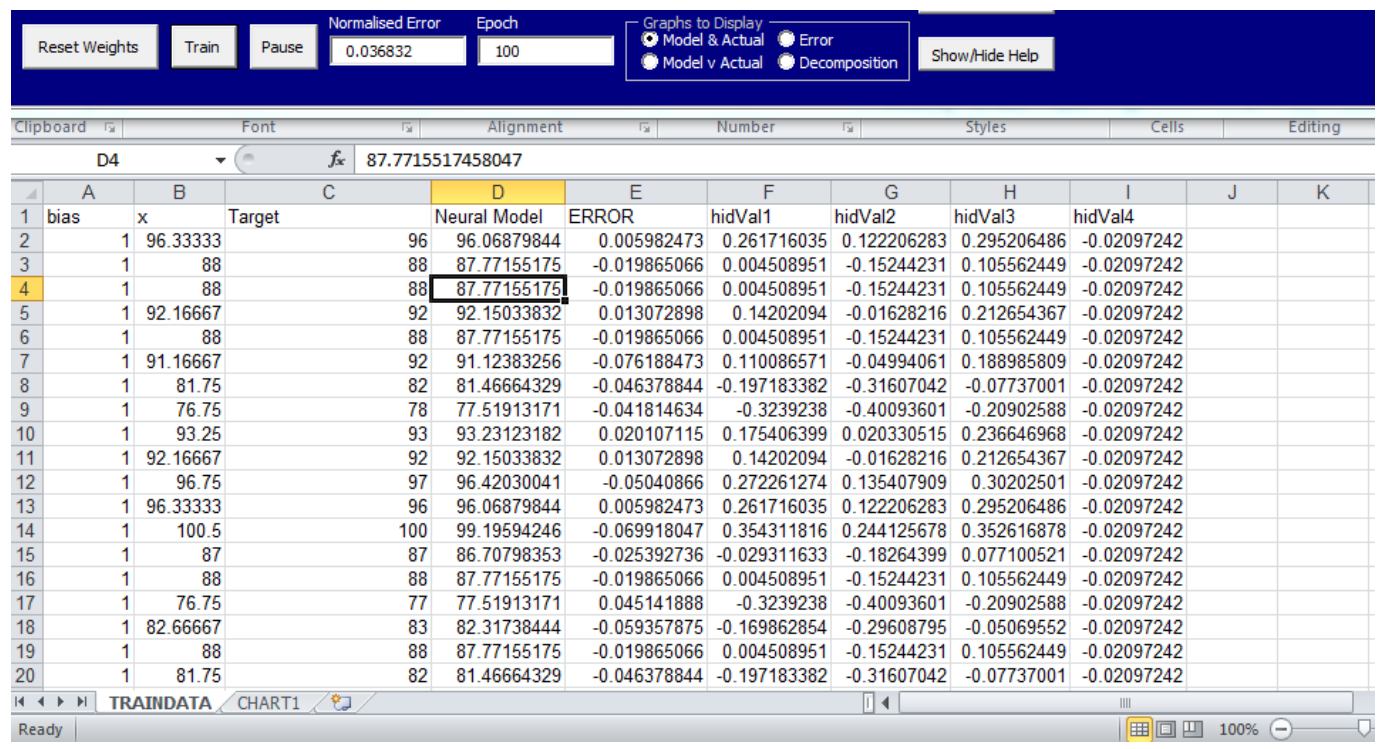

Figure 10. Calculations Using 3 Hidden Layers

In the above test, obtained the amount of error value 0.018902945. In this test, hidden layer used from 1 hidden layer to 5 hidden layers.

\subsection{System Testing}

One indicator of success in building a system is the fulfillment of functional and nonfunctional requirements of the system in work. In testing this system, using the black box testing method.

Table 3 System Testing

\begin{tabular}{|c|l|l|c|}
\hline No & \multicolumn{1}{|c|}{ Testing } & \multicolumn{1}{|c|}{ Target } & Test Result \\
\hline 1. & $\begin{array}{l}\text { Login process using nidn as } \\
\text { username and password }\end{array}$ & $\begin{array}{l}\text { Lecturers can only login } \\
\text { using nidn owned }\end{array}$ & Appropriate target \\
\hline 2. & $\begin{array}{l}\text { Lecturer input data process based } \\
\text { on nidn as the primary key }\end{array}$ & $\begin{array}{l}\text { There is no common nidn in } \\
\text { the system }\end{array}$ & Appropriate target \\
\hline 3. & $\begin{array}{l}\text { The process of input of lecturer } \\
\text { education data based on nidn } \\
\text { lecturer }\end{array}$ & $\begin{array}{l}\text { A cluster of lecturer } \\
\text { education data based on } \\
\text { nidn }\end{array}$ & Appropriate target \\
\hline 4. & $\begin{array}{l}\text { The process of research data } \\
\text { input lecturer based on nidn } \\
\text { lecturer }\end{array}$ & $\begin{array}{l}\text { Cluster research data } \\
\text { lecturer based on nidn }\end{array}$ & Appropriate target \\
\hline 5. & $\begin{array}{l}\text { Display dashboard menu after } \\
\text { the login process }\end{array}$ & $\begin{array}{l}\text { Display menu based on user } \\
\text { login level }\end{array}$ & Appropriate target \\
\hline
\end{tabular}




\begin{tabular}{|l|l|l|l|}
\hline 6. & $\begin{array}{l}\text { SKP data input form } \\
\text { simultaneously }\end{array}$ & $\begin{array}{l}\text { Data input form can be } \\
\text { customized based on user } \\
\text { needs }\end{array}$ & Appropriate target \\
\hline 7. & $\begin{array}{l}\text { SKP data assessment form based } \\
\text { on work unit cluster }\end{array}$ & $\begin{array}{l}\text { SKP data assessors can only } \\
\text { judge by a cluster of work } \\
\text { units }\end{array}$ & Appropriate target \\
\hline 8. & $\begin{array}{l}\text { Report data lecturer, education, } \\
\text { research, SKP, and assessment }\end{array}$ & $\begin{array}{l}\text { Reports in Microsoft Excel } \\
\text { format }\end{array}$ & Appropriate target \\
\hline 9. & Classification of educational data & $\begin{array}{l}\text { Educational data in } \\
\text { graphical form }\end{array}$ & Appropriate target \\
\hline 10. & Classification of research data & $\begin{array}{l}\text { Research Data in graphical } \\
\text { form }\end{array}$ & Appropriate target \\
\hline 11. & Classification of credit score data & Credit number data in graph & Appropriate target \\
\hline 12. & $\begin{array}{l}\text { Classification of SKP assessment } \\
\text { aspect data }\end{array}$ & $\begin{array}{l}\text { SKP grading aspect data in } \\
\text { graphical form }\end{array}$ & Appropriate target \\
\hline 13. & $\begin{array}{l}\text { Classification of SKP } \\
\text { performance data }\end{array}$ & $\begin{array}{l}\text { Graph of SKP performance } \\
\text { data }\end{array}$ & Appropriate target \\
\hline
\end{tabular}

\section{CONCLUSIONS}

From the research implementation of the artificial neural network back propagation in an employee target information system can be concluded that the application of artificial neural network back propagation to perform performance classification based on the achievement of SKP can run well.

By using this SKP system, the leadership becomes easier to know the map of human resources owned so that the target increase can be quickly compiled.

\section{REFERENCES}

Ardana YM Kusuma, 2013, Pemprograman PHP Dengan Codeigniter: Black Box, Jasakom Balazinski Marek, Czogala Ernest, Jemielniak Krzysztof dan Leski Jacek, 2002, Tool condition monitoring using artificial intelligence methods, Engineering Applications of Artificial Intelligence 15, 73 -80

Cerri Ricardo, Barros Rodrigo C, André C.P.L.F. de Carvalho, 2013, Hierarchical multi-label classification using local neural networks, Journal of Computer and Sistem Sciences, Available online 22 March.

Capparuccia Rosario, Leone Renato De, Marchitto Emilia, 2007, Integrating support vector machines and neural networks, Neural Networks 20,590 - 597.

Dai Qun dan Liu Ningzhong, 2012, Alleviating the problem of local minima in Backpropagation through competitive learning, Neurocomputing 94, 152-158

Daniele Soria, Jonathan M. Garibaldi, Federico Ambrogi, Eli M. Biganzoli, Ian O. Ellis, 2011, A ' non-parametric' version of The Naïve Bayes Classifier, Knowledge-Based Sistem $24,775-784$.

Emad W Saad dan Donald Ch II, 2007, Neural network explanation using inversion, Neural Networks 20, 78-93.

Hermawati Fajar Astuti, 2013, Data Mining, Penerbit Andi, Yogyakarta 
Hyunsoo Yoon, Cheong-Sool Park, Seok Kim Jundan Baek Jun-Geol, 2013, Algorithm learning based neural network integrating feature selection and classification, Expert Sistem with Applications 40, 231-241.

Kustono Djoko, Machbub Carmadi , Zainuddin, Pujogiri Putut, Zuardi Trisno , Hanafi Ivan, Hidayat A, Idris Abdurrachim dan Winarno Sugeng, 2010, Pedoman Beban Kerja dan Evaluasi Pelaksanaan Tridarma Perguruan Tinggi, Dirjen DIKTI, Jakarta

Kusrini dan Lutfi Emha Taufiq, 2009, Algoritma data mining, Penerbit Andi, Yogyakarta

Kusumadewi Sri, 2003, Artificial Intellegence (Teknik dan Aplikasinya), Penerbit Graha Ilmu, Yogyakarta

Melody Y. Kiang, A comparative assessment of classification methods, 2003, Decision Support Sistems 35, $441-454$

Moertini Sri, Veronica, 2007, Pengembangan Skalabilitas Algoritma Klasifikasi C4.5, Disertasi, Institute Teknologi Bandung, Bandung.

Oña Juan, Oña Rocio dan Calvo Francisco J, 2012, A classification tree approach to identify key factors of transit service quality, Expert Systems with Applications 39, 1116411171.

Polat Kemal dan Gunet Salih, A novel hybrid intelligent method based on C4.5 decision tree classifier and one-against-all approach for multi-class classification problems, expert system with the application (36) 2009, 1587-1592.

Purnomo Mauridhi Hery dan Kurniawan Agus, 2006, Supervised Neural Networks dan Aplikasinya, Penerbit Graha Ilmu, Yogyakarta

Puspitaningrum Diyah, 2006, Pengantar Jaringan Saraf Tiruan, Penerbit Andi, Yogyakarta

Prasetyo Eko, 2013, Data Mining : Konsep dan Aplikasi Menggunakan Matlab, Penerbit Andi, Yogyakarta

Sedarmayanti, 2007, Manajemene Sumberdaya Manusia, Reformasi Birokrasi dan Manajemen Pegawai Negeri Sipil, Refika Aditama, Bandung, Cetakan Keenam

Siang Jong Jek, 2005, Jaringan Syaraf Tiruan dan Pemprogramannya Menggunakan Matlab. Penerbit Andi, Yogyakarta

Setsirichok Damrongrit, Piroonratana Theera, Wongseree Waranyu, Usavanarong Touchpong, Paulkhaolarn Nuttawut, Kanjanakorn Chompunut, Sirikong Monchan, Limwongse Chanin dan Chaiyaratana Nachol, 2012, Classification of complete blood count and haemoglobin typing data by a C4.5decision tree, a naïve Bayes classifier and a multilayer perceptron forthalassaemia screening, Biomedical Signal Processing and Control 7, 202- 212

Sidik Betha, 2012, Framework Codeigniter, Penerbit Informatika, Bandung

Zhou Zhi-Hua, Member, IEEE, dan Jiang Yuan, Medical Diagnosis with C4.5 Rule Preceded by Artificial Neural Network Ensemble, IEEE, Transactions on Information Technology in Biomedicine

Zainuddin Muhamad, Hanafi Ivan, Kustono Djoko, Kumaidi, Haroen Yanuarsyah, Kuswarno Engkus, Sugiarto Bambang, Azwar Saifuddin, Wachjoe Conny K. dan Sujanti Sri, 2012, Buku Pedoman Sertifikasi Pendidik Untuk Dosen, Dirjen DIKTI, Jakarta 